\title{
Acute fluid shifts influence the assessment of serum vitamin $D$ status in critically ill patients
}

\author{
Anand Krishnan ${ }^{1}$, Judith Ochola ${ }^{1}$, Julie Mundy ${ }^{2}$, Mark Jones ${ }^{1}$, Peter Kruger ${ }^{1}$, Emma Duncan ${ }^{3}$, Bala Venkatesh ${ }^{1,4^{*}}$
}

\begin{abstract}
Introduction: Recent reports have highlighted the prevalence of vitamin D deficiency and suggested an association with excess mortality in critically ill patients. Serum vitamin D concentrations in these studies were measured following resuscitation. It is unclear whether aggressive fluid resuscitation independently influences serum vitamin D.

Methods: Nineteen patients undergoing cardiopulmonary bypass were studied. Serum $25(\mathrm{OH}) \mathrm{D}_{3}, 1 \alpha, 25(\mathrm{OH})_{2} \mathrm{D}_{3}$, parathyroid hormone, C-reactive protein (CRP), and ionised calcium were measured at five defined timepoints: T1 baseline, T2 - 5 minutes after onset of cardiopulmonary bypass (CPB) (time of maximal fluid effect), T3 - on return to the intensive care unit, T4 - 24 hrs after surgery and T5 - 5 days after surgery. Linear mixed models were used to compare measures at T2-T5 with baseline measures.

Results: Acute fluid loading resulted in a $35 \%$ reduction in $25(\mathrm{OH}) \mathrm{D}_{3}(59 \pm 16$ to $38 \pm 14 \mathrm{nmol} / \mathrm{L}, P<0.0001)$ and a $45 \%$ reduction in $1 \alpha, 25(\mathrm{OH})_{2} \mathrm{D}_{3}(99 \pm 40$ to $54 \pm 22 \mathrm{pmol} / \mathrm{L} P<0.0001)$ and $\mathrm{i}(\mathrm{Ca})(P<0.01)$, with elevation in parathyroid hormone $(P<0.0001)$. Serum $25(\mathrm{OH}) \mathrm{D}_{3}$ returned to baseline only at $\mathrm{T} 5$ while $1 \alpha, 25(\mathrm{OH})_{2} \mathrm{D}_{3}$ demonstrated an overshoot above baseline at T5 $(P<0.0001)$. There was a delayed rise in CRP at T4 and T5; this was not associated with a reduction in vitamin $D$ levels at these time points.
\end{abstract}

Conclusions: Hemodilution significantly lowers serum $25(\mathrm{OH}) \mathrm{D}_{3}$ and $1 \alpha, 25(\mathrm{OH})_{2} \mathrm{D}_{3}$, which may take up to 24 hours to resolve. Moreover, delayed overshoot of $1 \alpha, 25(\mathrm{OH})_{2} \mathrm{D}_{3}$ needs consideration. We urge caution in interpreting serum vitamin $D$ in critically ill patients in the context of major resuscitation, and would advocate repeating the measurement once the effects of the resuscitation have abated.

\section{Introduction}

Vitamin D is synthesised in the skin through UV action on 7-dehydrocholesterol, to cholecalciferol. It is transported in the blood by the Vitamin D binding protein (VDBP) to the liver where it undergoes 25 hydroxylation to form $25(\mathrm{OH}) \mathrm{D}_{3}$, which in turn undergoes $1 \alpha$ hydroxylation (especially, but not exclusively in the kidneys) to form $1 \alpha, 25(\mathrm{OH})_{2} \mathrm{D}_{3}$. Its traditionally recognised role is to maintain adequate serum calcium and phosphate levels, for bone mineralisation and optimal cardiac [1] and skeletal muscle function [2]. However, increasing data from biochemical, and molecular genetic studies indicate that vitamin $\mathrm{D}$ has a much wider range of actions, which are termed pleiotropic effects. These

\footnotetext{
* Correspondence: Bala_venkatesh@health.qld.gov.au

'Intensive Care Unit, Princess Alexandra Hospital, University of Queensland, Ipswich Road, Woolloongabba, QLD 4102, Australia Full list of author information is available at the end of the article
}

include potentiation of antimicrobial action, and cardioprotective and immunomodulatory effects [3]. The immunomodulatory properties of vitamin $\mathrm{D}$ have been shown to improve outcomes in transplant recipients [4], reduce relapses in multiple sclerosis [5], and may reduce the development of type I diabetes mellitus [6]. In the general population there is a $26 \%$ increase in all-cause mortality in those in the lowest quartile of $25(\mathrm{OH}) \mathrm{D}_{3}$ levels when compared to the highest quartile [7].

Awareness of the pleiotropic effects of Vitamin D has captured the interest of intensivists. Critically ill patients with prolonged stays in an intensive care unit may develop vitamin D deficiency for a number of reasons, including lack of exposure to sunlight, malnutrition, decreased renal $1 \alpha$ hydroxylation and increased tissue conversion of $25(\mathrm{OH}) \mathrm{D}_{3}$ to $1 \alpha, 25(\mathrm{OH})_{2} \mathrm{D}_{3}$ during acute stress and the inflammatory response [8,9]. An additional contributor to vitamin D deficiency in critically ill
C Biomed Central 
patients may be perturbations in serum albumin and VDBP. Reductions in serum concentrations of these proteins will influence total circulating concentrations of vitamin D [10]. Published data suggest a significantly higher incidence of vitamin $\mathrm{D}$ deficiency and bone resorption in chronically critically ill patients [11]. Van den Berghe et al. [9] showed the levels of both 25(OH) $\mathrm{D}_{3}$ and $1 \alpha, 25(\mathrm{OH})_{2} \mathrm{D}_{3}$ are low on admission to ICU compared to age-matched controls. Evidence from a recent case series [12] demonstrated significantly worse outcomes for patients with reduced serum levels of 25 $(\mathrm{OH}) \mathrm{D}_{3}$ in critical illness, although a direct causal effect has not been proven. All this has generated renewed interest in the pharmacodynamics of vitamin D, especially in the critically ill patient. This together with accumulating evidence on hypovitaminosis D in the critically ill has prompted calls for supplementation in these patients.

However, there are several limitations to the published data. It is frequently unclear as to when the "baseline" measurements were performed. Critically ill patients on admission to the hospital or intensive care unit often receive large volumes of intravenous fluids to correct hypovolemia and hypotension, and the extent of volume replacement is often directly related to the severity of acute illness [13]. Acute expansion of the intravascular volume is associated with reduction in levels of various electrolytes, proteins and blood components due to hemodilution [14]. Whether the post dilution effect would be responsible for the observed low baseline levels of $25(\mathrm{OH}) \mathrm{D}_{3}$ needs investigation. Moreover, critically ill patients are often "waterlogged" and are slow in clearing body water. Consequently any dilutional effect of baseline resuscitation may have an impact on plasma concentrations beyond the resuscitation period. How this will influence the interpretation of Vitamin $\mathrm{D}$ in the peri-resuscitation period remains unclear. Finally, most studies have examined $25(\mathrm{OH}) \mathrm{D}_{3}$, while the active hormone is $1 \alpha, 25(\mathrm{OH})_{2} \mathrm{D}_{3}$. Whether changes in $1 \alpha, 25(\mathrm{OH})_{2} \mathrm{D}_{3}$ parallel those of $25(\mathrm{OH}) \mathrm{D}_{3}$, during volume loading and clearance also remain unknown. Of note, the water-solubility and half-lives of these different forms of vitamin D are quite different [15].

We chose cardiopulmonary bypass as a clinical model to test this question. Patients undergoing routine elective cardiac surgery are not acutely unwell, and receive a standard volume fluid load when going on to cardiopulmonary bypass $(\mathrm{CPB})$ which is cleared over the next several days. They usually have a predictable course of recovery and hence provide an ideal model to look at the effects of acute fluid loading on vitamin D levels.

\section{Materials and methods}

This study was conducted at the Princess Alexandra Hospital in Brisbane, a tertiary-care referral centre with one of the biggest cardiac surgical services in Australia. The study was approved by the institution's Human Research Ethics Committee and written, informed consent was obtained from patients prior to inclusion.

\section{Inclusion criteria}

Patients aged 18 years or older scheduled to undergo elective cardiac surgery under cardiopulmonary bypass were eligible for enrolment into the study.

Patients were excluded from the study if they met any of the following criteria: 1) if they were undergoing urgent cardiac surgery, 2) if they had chronic hepatic dysfunction (grade greater than Child-Pugh A), 3) if they had renal dysfunction (creatinine $>200$ micromol/L).

The conduct of anaesthesia and surgery was as per standard practice. Briefly, the cardiopulmonary bypass (CPB) circuit incorporated a membrane oxygenator (Dideco Avante, Cellplex, Sorin, Mirondola, Italy) and heart lung machine (Jostra HL 20, Maquet Critical Care $\mathrm{AB}$, Solna, Sweden). Pump rate was set at $2.4 \mathrm{~L} /$ minute/ $\mathrm{m}^{2}$ and temperature ranged from 32 to $35^{\circ} \mathrm{C}$. The circuit was primed with $2 \mathrm{~L}$ of Plasma-Lyte $148\left(\mathrm{Na}^{+} 140 \mathrm{mmol} /\right.$ $\mathrm{L}, \mathrm{Cl}^{-} 98 \mathrm{mmol} / \mathrm{L}, \mathrm{K}^{+} 5 \mathrm{mmol} / \mathrm{L}, \mathrm{Mg}^{++} 1.5 \mathrm{mmol} / \mathrm{L}$, Acetate $27 \mathrm{mmol} / \mathrm{L}$, Gluconate $23 \mathrm{mmol} / \mathrm{L}$ ), a commercially available balanced crystalloid solution. (Baxter Healthcare, Toongabbie, NSW, Australia).

Following surgery all patients were admitted to the intensive care unit for 24 hours. They were all ventilated postoperatively as per standard protocol. Vasoactive drugs and external cardiac pacing were commenced according to clinical need. In addition, all patients received stress ulcer prophylaxis, analgesia, and anticoagulation prophylaxis with subcutaneous heparin and aspirin routinely commenced the morning after their operation. Patients were discharged from the ICU after 24 hours and from the hospital between Day 5 and Day 7 postoperatively.

Fluid intake and output were recorded from the commencement of surgery till discharge from the hospital; these were done relative to a baseline value of zero litres just prior to commencement of surgery. Patients were weighed at baseline, 24 hours after surgery and on Day 5.

\section{Serum measurements}

Blood was sampled at the following time points:

T1) Immediately before commencing cardio-pulmonary bypass; T2) Five minutes after commencement of bypass, prior to placement of the aortic cross-clamp (immediately after a large increase in blood volume due to the mixture with the CPB circuit prime); T3) On return to the intensive care unit after surgery, T4) 24 hours after surgery, T5) 5 days after surgery.

At each time point serum $25(\mathrm{OH}) \mathrm{D}_{3}, 1 \alpha, 25(\mathrm{OH})_{2} \mathrm{D}_{3}$, parathyroid hormone (PTH), total and ionised calcium, 
total magnesium and phosphate and C-reactive protein were measured.

\section{Assays}

Serum $25(\mathrm{OH}) \mathrm{D}_{3}$ and $1 \alpha, 25(\mathrm{OH})_{2} \mathrm{D}_{3}$ were measured by LC MSMS system (Waters Corp Milford, MA, USA) (between-run coefficient of variations (CV\%): vitamin D2 at $42.0 \mathrm{nmol} / \mathrm{L} 5.9 \%$, and at $91.0 \mathrm{nmol} / \mathrm{L} 7.7 \%$; vitamin D3 at $76.0 \mathrm{nmol} / \mathrm{L} 15.3 \%$, and at $181 \mathrm{nmol} / \mathrm{L} \mathrm{6.8 \% ).} \mathrm{Para-}$ thormone estimation was an immunoassay performed on Siemens Immulite analyser (Siemens Healthcare Diagnostics, Medfield, MA, USA) with antibodies specific for the $\mathrm{C}$-terminal region thereby recognising only intact PTH (between-run CV\%: at $1.18 \mathrm{pmol} / \mathrm{L} 8.8 \%$; at 6.69 $\mathrm{pmol} / \mathrm{L} 5.3 \%$, and at $42.87 \mathrm{pmol} / \mathrm{L} 5.0 \%$, The total calcium $(\mathrm{Ca})$, magnesium $\left(\mathrm{Mg}^{2+}\right)$ and inorganic phosphorus $\left(\mathrm{PO}_{4}{ }^{3-}\right)$ were measured on Beckman DxC 800 general chemistry analysers (Beckman Coulter Diagnostics, Fullerton, CA, USA) by ion selective electrode, and photometric methods (between-run precision limits: $\mathrm{Ca}$ at $1.98 \mathrm{mmol} / \mathrm{L} 1.7 \%$ and at $2.96 \mathrm{mmol} / \mathrm{L} 1.7 \% ; \mathrm{Mg}^{2+}$ at $0.75 \mathrm{mmol} / \mathrm{L} 3.8 \%$ and at $1.60 \mathrm{mmol} / \mathrm{L} 2.4 \% ; \mathrm{PO}_{4}{ }^{3-}$ at $0.98 \mathrm{mmol} / \mathrm{L} 5.1 \%$ and at $3.19 \mathrm{mmol} / \mathrm{L} 5.1 \%)$. The $\mathrm{i}(\mathrm{Ca})$ was measured on Siemens Rapidlab 1265 blood gas analysers (Siemens Healthcare Diagnostics, Medfield, MA, USA) by ion selective electrode (between-run CVs: at $0.80 \mathrm{mmol} / \mathrm{L} 1.8 \%$ and at $1.60 \mathrm{mmol} / \mathrm{L} 1.5 \%)$. CRP was measured on Beckman DxC800 general chemistry analysers using a turbidimetric method (between-run CVs: at $4.9 \mathrm{mg} / \mathrm{L} 5.3 \%$ and at $10.5 \mathrm{mg} / \mathrm{L} \mathrm{3.6 \% ).}$

\section{Statistical methods}

The data were analysed using SAS version 9.2 for Windows (SAS Institute, Cary, NC, USA). Linear mixed models were used to compare the measures of vitamin D, electrolytes and CRP taken at time-points 2, 3, 4 and 5 with measures taken at baseline (time-point 1 ). In separate analyses, the vitamin D measures were specified as dependent variables in linear mixed models and then tested for association with CRP, fluid balance and electrolytes. R-square was used to express the magnitude of correlation between the vitamin $\mathrm{D}$ measures and the other parameters [16].

\section{Results}

Nineteen patients were included in the study. All patients successfully underwent cardiac surgery and were discharged live from the hospital. The baseline, demographic and operative data are summarised in Table 1 .

\section{Changes in fluid balance and body weight}

Baseline values were taken as zero fluid balance status. Predictably, there were positive fluid balances at T2
$(3.5 \pm 1.2 \mathrm{~L}), \mathrm{T} 3(3.0 \pm 1.5 \mathrm{~L})$, and T4 $(2.5 \pm 1.2 \mathrm{~L})$. On Day 5, the fluid balance had started to return towards baseline $(1.1 \pm 0.8 \mathrm{~L})$. Changes in bodyweight followed fluid balance profile. The mean bodyweight at baseline was $88 \pm 20 \mathrm{~kg}$, increased to $91 \pm 22 \mathrm{~kg}$ at $\mathrm{T} 4$ and returned to $87 \pm 21 \mathrm{~kg}$ at $\mathrm{T} 5$. All patients received at least one dose of frusemide as part of routine postoperative care. None of the patients received blood transfusions during $\mathrm{CPB}$.

\section{Serum Vitamin $D\left(25(\mathrm{OH}) \mathrm{D}_{3}\right.$ and $\left.1 \alpha, 25(\mathrm{OH})_{2} \mathrm{D}_{3}\right)$}

The mean baseline, serum $25(\mathrm{OH}) \mathrm{D}_{3}$ was $59 \pm 16 \mathrm{nmol} /$ L. At T2, (immediately after mixture with the pump prime), there was a $35 \%$ reduction in $25(\mathrm{OH}) \mathrm{D}_{3}$ to $38 \pm$ $14 \mathrm{nmol} / \mathrm{L}(P<0.0001)$. Serum $25(\mathrm{OH}) \mathrm{D}_{3}$ continued to remain low and returned to baseline only on Day 5 (T5).

Serum $1 \alpha, 25(\mathrm{OH})_{2} \mathrm{D}_{3}$ appeared to follow a similar temporal course to that of $25(\mathrm{OH}) \mathrm{D}_{3}$ initially. The mean baseline concentrations were $99 \pm 40 \mathrm{pmol} / \mathrm{L}$ Hemodilution resulted in significant reductions $(45 \%)$ in $1,25(\mathrm{OH})$ ${ }_{2} \mathrm{D}_{3}$ to $54 \pm 22 \mathrm{pmol} / \mathrm{L}(P<0.0001)$. In contrast to $25(\mathrm{OH}) \mathrm{D}_{3}$, concentrations of $1 \alpha, 25(\mathrm{OH})_{2} \mathrm{D}_{3}$ demonstrated a significant overshoot above baseline on Day 5 (T5) to $214 \pm 91 \mathrm{pmol} / \mathrm{L}(P<0.0001)$. These are illustrated graphically in Figure 1.

\section{Serum PTH, calcium, magnesium and phosphate}

Changes in serum PTH appeared to follow an opposite course to that of $25(\mathrm{OH}) \mathrm{D}_{3}$ and $1 \alpha, 25(\mathrm{OH})_{2} \mathrm{D}_{3}$. Baseline levels $(21 \pm 19 \mathrm{pmol} / \mathrm{L})$ were elevated, rose significantly with hemodilution to $41 \pm 25 \mathrm{pmol} / \mathrm{L}(P<0.0001)$ and returned to baseline at 24 hours and levels were significantly low $(5 \pm 3 \mathrm{pmol} / \mathrm{L})$ on Day 5 . Changes in serum ionised calcium, magnesium and phosphate are shown in Table 2 and those of ionised calcium and PTH are shown in Figure 2.

\section{Serum CRP}

Serum CRP levels were within the normal range at baseline $(6 \pm 9 \mathrm{mg} / \mathrm{L})$. There was a statistically significant (but clinically insignificant) drop with hemodilution $(4 \pm$ $5 \mathrm{mg} / \mathrm{L}, P=0.04$ ). At 24 hours (T4) significant elevations in CRP with respect to baseline were noticed (82 \pm $40 \mathrm{mg} / \mathrm{L}, P<0.0001)$, and remained persistently elevated even on Day $5(134 \pm 58 \mathrm{mg} / \mathrm{L}, P<0.01)$.

\section{Serum albumin and creatinine}

The mean baseline serum albumin was $34 \pm 4 \mathrm{~g} / \mathrm{L}$. At T2, the concentrations fell by $30 \%$ to $24 \pm 4 \mathrm{~g} / \mathrm{L}(P<0.0001)$, followed by a gradual return towards baseline over the following time points: T3 to $30 \pm 4 \mathrm{G} / \mathrm{L}(P<0.001)$, T4 to $32 \pm 4 \mathrm{G} / \mathrm{L}(P=0.11)$ and T5 $32 \pm 3 \mathrm{~g} / \mathrm{L}(P=0.06)$.

The mean baseline creatinine was $81 \pm 22 \mu \mathrm{mol} / \mathrm{L}$ (normal reference range $<90 \mu \mathrm{mol} / \mathrm{L}$ ), which fell to 
Table 1 Demographic data

\begin{tabular}{ll}
\hline Total number of patients & 19 \\
Male/female distribution & $14 \mathrm{M}, 5 \mathrm{~F}$ \\
Mean age (yrs) & $59 \pm 12$ \\
Types of operations & $7 \mathrm{CABG}, 11$ valvular procedures and \\
& $1 \mathrm{CABG}+$ valve \\
& $80 \pm 22$ \\
Mean baseline creatinine & \\
(micromol/L) & $88 \pm 21$ \\
Mean Baseline weight (kg) & $30 \pm 6$ \\
Mean BMI (kg/m²) & $108 \pm 49$ \\
Mean bypass time (min) & $78 \pm 45$ \\
Mean cross clamp time (min) &
\end{tabular}

$\mathrm{BMI}$, body mass index; CABG, coronary artery bypass grafts.

$71 \pm 16 \mu \mathrm{mol} / \mathrm{L}$ at T2 $(P=0.002)$. There was both a clinically and a statistically insignificant overshoot from baseline at T3, T4 and T5: $89 \pm 38 \mu \mathrm{mol} / \mathrm{L}(P=$ $0.23), 90 \pm 40 \mu \mathrm{mol} / \mathrm{L}(P=0.15)$ and $90 \pm 43 \mu \mathrm{mol} / \mathrm{L}$ respectively $(P=0.2)$.

\section{Effect of different variables on vitamin D}

Using $25(\mathrm{OH}) \mathrm{D}_{3}$ as a dependent variable, linear mixed models were used and tested for independent association of changes in $25(\mathrm{OH}) \mathrm{D}_{3}$ with fluid balance, CRP and electrolytes. Fluid balance showed a signifcant negative association with both $25(\mathrm{OH}) \mathrm{D}_{3}$ (effect size -4.9 , CI -6.4 to $-3.4, P<0.0001$ ) and $1 \alpha, 25(\mathrm{OH})_{2} \mathrm{D}_{3}$ (effect size $-14.0, \mathrm{CI}-22$ to $-6, P<0.001)$. Changes in serum albumin were strongly correlated with $25(\mathrm{OH}) \mathrm{D}_{3}(P<$ $0.0001)$ and $1 \alpha, 25(\mathrm{OH})_{2} \mathrm{D}_{3}(P<0.0002)$. Changes in serum creatinine were correlated with $25(\mathrm{OH}) \mathrm{D}_{3},(P<$ $0.05)$, but not $1 \alpha, 25(\mathrm{OH})_{2} \mathrm{D}_{3}(P=0.94)$.

Serum CRP showed a significant positive association with both $25(\mathrm{OH}) \mathrm{D}_{3}$ (effect size $0.08,0.02$ to $0.14, P<$ 0.01 ) and $1 \alpha, 25(\mathrm{OH})_{2} \mathrm{D}_{3}$ (effect size 0.62 , CI 0.39 to 0.84), $P<0.0001)$.

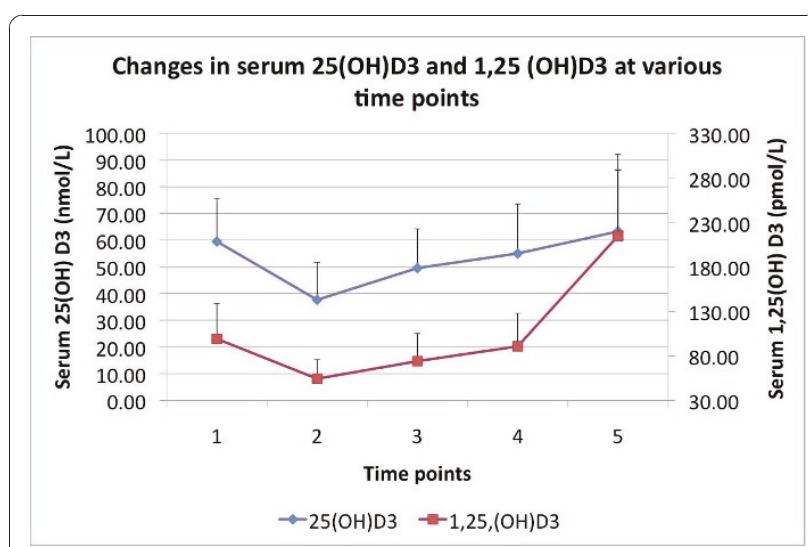

Figure 1 An illustration of the changes in serum $25(\mathrm{OH}) \mathrm{D}_{3}$ (filled diamonds) and $1 \alpha, 25(\mathrm{OH})_{2} \mathrm{D}_{3}$ (filled squares) concentrations across the five time points.
Ionised calcium was strongly associated with both $25(\mathrm{OH}) \mathrm{D}_{3}$ (effect size 67.2 (CI 47.6 to $87, P<0.0001$ ) and $1 \alpha, 25(\mathrm{OH})_{2} \mathrm{D}_{3}$ (effect size 249 (CI 127 to $371, P<$ $0.0001)$. Total calcium was also strongly associated with both $25(\mathrm{OH}) \mathrm{D}_{3}(P<0.0001)$ and $1 \alpha, 25(\mathrm{OH})_{2} \mathrm{D}_{3}(P<$ $0.0001)$. Phosphate concentrations did not show any significant association with both $25(\mathrm{OH}) \mathrm{D}_{3}$ and $1 \alpha, 25(\mathrm{OH})$ ${ }_{2} \mathrm{D}_{3}$ concentrations. Magnesium was less strongly associated with $25(\mathrm{OH}) \mathrm{D}_{3}$ than calcium $(P<0.05)$.

There was no association between changes in fluid balance and CRP (effect size -4.1, CI -11.3 to 3.1, $P=0.26)$.

\section{Classification of patient's vitamin D status at various time points}

Table 3 illustrates the number of patients who would have been classified as vitamin $\mathrm{D}$ insufficient or deficient at various time points based on cut offs of $25(\mathrm{OH}) \mathrm{D}_{3}$ of $60 \mathrm{nmol} / \mathrm{L}$ and $30 \mathrm{nmol} / \mathrm{L}$, respectively.

The individual patient's endocrine data, calcium and albumin concentrations at various time points with changes in fluid balance at each of those time points are supplied in a table form and available in Additional file 1.

\section{Discussion}

The cardinal findings of the study are that intravascular volume loading significantly affects both $25(\mathrm{OH}) \mathrm{D}_{3}$ and $1 \alpha, 25(\mathrm{OH})_{2} \mathrm{D}_{3}$. Changes in $25(\mathrm{OH}) \mathrm{D}_{3}$ and $1 \alpha, 25(\mathrm{OH})$ ${ }_{2} \mathrm{D}_{3}$ were accompanied by reciprocal alterations in PTH concentrations. Both volume shifts and inflammatory response appeared to have independent effects on both $25(\mathrm{OH}) \mathrm{D}_{3}$ and $1 \alpha, 25(\mathrm{OH})_{2} \mathrm{D}_{3}$ concentrations.

\section{Changes in serum Vitamin D and PTH}

Volume loading clearly appeared to impact on $25(\mathrm{OH})$ $\mathrm{D}_{3}$ and $1 \alpha, 25(\mathrm{OH})_{2} \mathrm{D}_{3}$. At baseline, $25(\mathrm{OH}) \mathrm{D}_{3}$, was low in keeping with the reported prevalence of hypovitaminosis $\mathrm{D}$ in the community.

On initiation of $\mathrm{CPB}$, there was an increase in the circulating blood volume by a volume of $2 \mathrm{~L}$ owing to the obligatory addition of the pump prime. Assuming a normal blood volume of $5 \mathrm{~L}$, this prime would increase the blood volume by an additional $40 \%$. Therefore, reductions of $25(\mathrm{OH}) \mathrm{D}_{3}$, and $1 \alpha, 25(\mathrm{OH})_{2} \mathrm{D}_{3}$ of $35 \%$ and $45 \%$ respectively at $\mathrm{T} 2$ would be consistent with this dilution effect. Albumin binds to Vitamin D and, therefore, reductions in albumin will be accompanied by parallel reductions in the latter. Further support for this haemodilution effect is shown by the strong correlation between changes in serum albumin and vitamin D. Other possible explanations include adsorption of vitamin D by the plastic tubing and catabolism of these hormones through 24-hydroxylation to calcitroic acid 
Table 2 Changes in serum total and ionised calcium, magnesium and phosphate

\begin{tabular}{lccccc}
\hline & T1 & T2 & T3 & T4 & T5 \\
\hline Total calcium (mmol/L) & $2.2 \pm 0.1$ & $1.9 \pm 0.1^{*}$ & $2.1 \pm 0.2^{*}$ & $2.1 \pm 0.1^{*}$ & $2.3 \pm 0.1^{*}$ \\
$\mathrm{i}[\mathrm{Ca}](\mathrm{mmol} / \mathrm{L})$ & $1.1 \pm 0.1$ & $0.9 \pm 0.1^{*}$ & $1.1 \pm 0.1$ & $1.1 \pm 0.1$ & $1.2 \pm 0.04$ \\
$\mathrm{Mg}^{++}(\mathrm{mmol} / \mathrm{L})$ & $1.1 \pm 0.4$ & $1.3 \pm 0.4$ & $1.3 \pm 0.2$ & $1.1 \pm 0.2$ & $0.9 \pm 0.1^{*}$ \\
$\mathrm{PO}^{3-}(\mathrm{mmol} / \mathrm{L})$ & $1.1 \pm 0.2$ & $0.9 \pm 0.2^{*}$ & $1.0 \pm 0.2^{*}$ & $1.2 \pm 0.3$ & $1.1 \pm 0.3$ \\
\hline
\end{tabular}

*Significantly different from baseline $(P<0.01) . T 1$ - baseline, $\mathrm{T} 2$ - five minutes after onset of cardiopulmonary bypass (CPB) (time of maximal fluid effect), T3 - on return to the intensive care unit, T4 - 24 hrs after surgery, T5 - five days after surgery.

[17]. Another possibility to consider is a reduction in serum VDBP concentrations from dilution as well adsorption to plastic as it is a protein and, therefore, may carry an electrical charge. However, the strong temporal relationship of serum concentrations to hemodilution, the rapidity of the drop together with a subsequent rise with fluid clearance and the magnitude of the drop being explained by the proportional rise in circulating volume argue in favour of a dilution effect as the preponderant cause. Plasma concentrations of these hormones started to rise by T3. This is likely due to intravascular volume losses owing to separation from $\mathrm{CPB}$, surgical losses and diuresis. Values only reached baseline by 24 hours (T4) in the case of $1 \alpha, 25(\mathrm{OH})_{2} \mathrm{D}_{3}$, while statistically significant differences were still noticeable for $25(\mathrm{OH}) \mathrm{D}_{3}$ at this time point.

At $\mathrm{T} 5,25(\mathrm{OH}) \mathrm{D}_{3}$ returned to baseline, while $1 \alpha, 25$ $(\mathrm{OH})_{2} \mathrm{D}_{3}$ demonstrated a statistically significant overshoot from baseline. The mechanism of the delayed rise in $1 \alpha, 25(\mathrm{OH})_{2} \mathrm{D}_{3}$ is unclear. The most likely explanation is the induction of $1-\alpha$ hydroxylase by PTH. The rise in PTH at T2 may be significant. PTH-dependent synthesis of new 1- $\alpha$ hydroxylase takes several hours and it is therefore likely that the initial rise in $\mathrm{PTH}$ was accompanied by a delayed rise in $1 \alpha, 25(\mathrm{OH})_{2} \mathrm{D}_{3}$ [18].

Moreover, there was also evidence of inflammation as evidenced by a delayed rise in CRP. Macrophages are

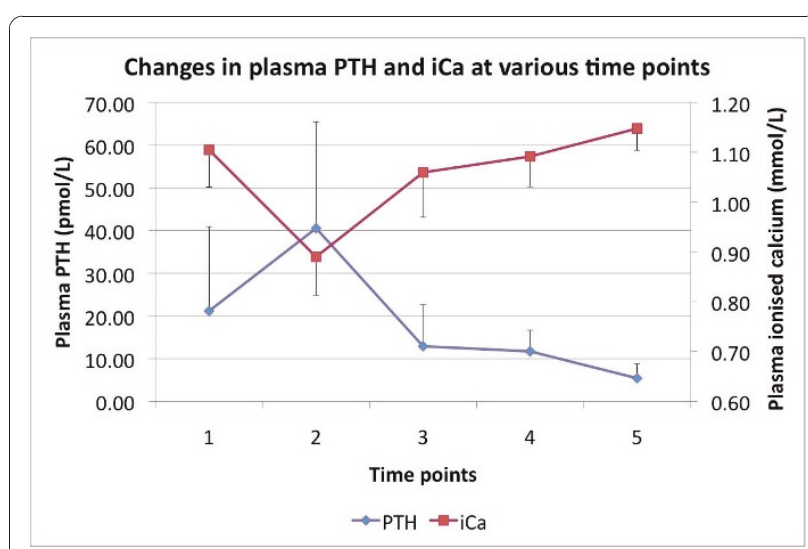

Figure 2 An illustration of the changes in serum PTH (filled diamonds) and ionised calcium (filled squares) concentrations across the five time points. potent sources of 1 - $\alpha$ hydroxylase and may also have contributed to the elevated $1 \alpha, 25(\mathrm{OH})_{2} \mathrm{D}_{3}$ levels through extra renal production of $1 \alpha, 25(\mathrm{OH})_{2} \mathrm{D}_{3}$ [19]. Alterations in VDBP are known to influence monocyte responses to $25(\mathrm{OH})_{2} \mathrm{D}_{3}$ and $1 \alpha, 25(\mathrm{OH})_{2} \mathrm{D}_{3}[20]$. Whether it played a role in the delayed rise in $1 \alpha, 25(\mathrm{OH})_{2} \mathrm{D}_{3}$ remains speculative. Support for the extra-renal contribution to the delayed rise in $1 \alpha, 25(\mathrm{OH})_{2} \mathrm{D}_{3}$ also comes from the lack of a strong correlation between creatinine levels and $1 \alpha, 25(\mathrm{OH})_{2} \mathrm{D}_{3}$. Other more chronic causes appear unlikely as the values were normal at baseline only five days prior.

We also found that PTH levels further rose significantly after commencement of $\mathrm{CPB}$. The reduction in ionised calcium as a result of hemodilution and chelation by acetate-containing fluid used in priming the $\mathrm{CPB}$ may be responsible for the rapid rise in $\mathrm{PTH}$, as part of the normal physiological response to hypocalcaemia. However, patients also had a significant and abrupt increase in serum magnesium which acutely increases PTH secretion. It is not possible in this model to distinguish between these stimuli for PTH secretion.

\section{Clinical significance of our findings}

To our knowledge this is the first study to examine the effects of volume loading on serum vitamin D concentrations. Our data clearly demonstrate the impact of fluid loading on serum vitamin D. Over the past decade, some reports have highlighted the prevalence of vitamin $\mathrm{D}$ deficiency and suggested an association with excess mortality in critically ill patients $[9,12]$. Recently, Lucidarme et al. identified a high prevalence of $25(\mathrm{OH}) \mathrm{D}_{3}$

Table 3 Proportion of patients who would have been classified as Vitamin D insufficient or deficient at various time points

\begin{tabular}{lccccc}
\hline & T1 & T2 & T3 & T4 & T5 \\
\hline $\begin{array}{l}\text { Vitamin D insufficiency }\left(25(\mathrm{OH}) \mathrm{D}_{3}\right. \\
<60 \mathrm{nmol} / \mathrm{L})\end{array}$ & $47 \%$ & $89 \%^{*}$ & $68 \%$ & $53 \%$ & $47 \%$ \\
$\begin{array}{l}\text { Vitamin D deficiency }\left(25(\mathrm{OH}) \mathrm{D}_{3}\right. \\
<30 \mathrm{nmol} / \mathrm{L})\end{array}$ & $5 \%$ & $37 \%^{* *}$ & $11 \%$ & $11 \%$ & $6 \%$ \\
\hline
\end{tabular}

${ }^{*} P<0.01$, significantly different from baseline.

${ }^{*} P<0.05$, significantly different from baseline.

T1 - baseline, T2 - five minutes after onset of cardiopulmonary bypass (CPB)

(time of maximal fluid effect), T3 - on return to the intensive care unit, T4 - 24 hrs after surgery, T5 - five days after surgery. 
insufficiency and deficiency in a prospective observational study of 134 critically ill patients [21]. They identified albumin, spring admission and SAPS II score as predictors of hypovitaminosis but levels of $1 \alpha, 25(\mathrm{OH})$ ${ }_{2} \mathrm{D}_{3}$ were not estimated. More importantly, in none of the above studies have the authors specified the timing of blood sample collection in relationship to fluid resuscitation. It is, therefore, unclear whether aggressive fluid resuscitation may have influenced serum vitamin D concentrations. In Table 3 the data clearly illustrate the potential for misclassification of patients as Vitamin D insufficient or deficient purely from a fluid effect. Moreover, critically ill patients are often water logged and are unable to clear a fluid load owing to hypoalbuminemia, renal dysfunction, and high ADH levels. Consequently any effects of a fluid load may be longstanding. In patients with severe baseline deficiency such as $25(\mathrm{OH})$ $\mathrm{D}_{3}$ values $<15 \mathrm{nmol} / \mathrm{L}$, it is likely that fluid loading may not have a significant physiological impact. The distribution space of $25(\mathrm{OH}) \mathrm{D}_{3}$ is similar to that of plasma, while $1 \alpha, 25(\mathrm{OH})_{2} \mathrm{D}_{3}$ is closer to that of intracellular water. Consequently the tonicity of the diluting fluid and the resultant expansion of the intravascular and the interstitial space become relevant. Based on our data, we would urge caution in interpreting serum vitamin $D$ in critically ill patients in the context of major resuscitation and would advocate repeating the measurement once the effects of the resuscitation have abated. While not examined in this study, another potential source of error in assessing vitamin D status is the assay variability as differences in vitamin $\mathrm{D}$ concentrations have been reported on the same sample depending on the methodology used [22].

Inflammatory response has been suggested to reduce Vitamin D concentrations [9]. In this study, biochemical evidence of inflammatory response began to emerge only 24 hours after bypass in keeping with previously published data; however this was accompanied by a rise in $1 \alpha, 25(\mathrm{OH})_{2} \mathrm{D}_{3}$ and there was a strong association between CRP and $25(\mathrm{OH}) \mathrm{D}_{3}$ and $1 \alpha, 25(\mathrm{OH})_{2} \mathrm{D}_{3}$.

\section{Limitations of the study}

Although the study is limited by the small sample size, the effect size was large enough to produce significant results. As stated earlier, the model of CPB was chosen because, patients undergoing routine elective cardiac surgery are not acutely unwell, hemodilution is an integral aspect of cardiopulmonary bypass (CPB) which is cleared subsequently and these patients usually, have a predictable course of recovery. Although the lower levels of patient acuity and minimal organ dysfunction raise the question whether these results can be transposed to other groups of critically ill patients, we assert that acute physiological effects of hemodilution are likely to be comparable across various patient groups, although the magnitude of the effect may be variable. As the protocol did not incorporate measurements between Day 1 and Day 5, it was not possible to elucidate the mechanism behind delayed changes in vitamin D concentrations. The measurement of VDBP levels would have provided useful information in terms of understanding of the mechanisms. $\mathrm{CPB}$ also initiates an inflammatory response; however, this is often a delayed process manifesting 12 to 24 hours after bypass (as observed in this study), whilst the major volume changes occurred soon after commencement of CPB. The early changes are therefore likely to be due to volume effects. Moreover, analysis of our data also showed that fluid shifts correlated with changes in vitamin D but not CRP.

\section{Conclusions}

In conclusion, hemodilution and acute fluid shifts significantly lower serum $25(\mathrm{OH}) \mathrm{D}_{3}$ and $1 \alpha, 25(\mathrm{OH})_{2} \mathrm{D}_{3}$. These may take up to 24 hours to resolve. The magnitude of changes in $25(\mathrm{OH}) \mathrm{D}_{3}$ and $1 \alpha, 25(\mathrm{OH})_{2} \mathrm{D}_{3}$ appeared to be proportional to the extent of volume change. Based on our data, we would urge caution in interpreting serum vitamin $D$ in critically ill patients in the context of major resuscitation and would advocate repeating the measurement once the effects of resuscitation have abated.

\section{Key messages}

- Acute fluid loading during critical illness markedly reduces serum $25(\mathrm{OH}) \mathrm{D}_{3}$ and $1 \alpha, 25(\mathrm{OH})_{2} \mathrm{D}_{3}$ concentrations.

- Serum concentrations may take up to 24 hours to return to baseline.

- We urge caution in interpreting serum vitamin D in critically ill patients in the context of major resuscitation and would advocate repeating the measurements once the effects of resuscitation have abated.

\section{Additional material}

Additional file 1: Additional tables. Table S1: Changes in individual patients' serum vitamin D, parathormone, calcium (total and ionised), creatinine and albumin concentrations at various time points with corresponding values for fluid balance. Table S2: Changes in patients' creatinine, albumin, fluid balance and weight values at various time points.

\section{Abbreviations \\ CPB: Cardiopulmonary bypass; CRP: C-reactive protein; $\mathrm{CA}^{2+}$ : serum total calcium; $\left[\mathrm{CA}^{2+}\right.$ ]: Serum ionised calcium; $\mathrm{MG}^{2+}$ : serum magnesium; $\left(\mathrm{PO}_{4}{ }^{3-}\right)$ : Serum inorganic phosphorus; PTH: Parathormone; $25(\mathrm{OH}) \mathrm{D}_{3}$ : 25-hydroxy vitamin $\mathrm{D} 3 ; 1 \alpha, 25(\mathrm{OH})_{2} \mathrm{D}_{3}$ : 1,25-dihydroxy vitamin $\mathrm{D} 3$.}

\section{Acknowledgements}

We would like to acknowledge the role of Goce Dimeski and the laboratory staff in the Department of Chemical Pathology at the Princess Alexandra Hospital for their assistance with the laboratory assays. 


\section{Author details}

'Intensive Care Unit, Princess Alexandra Hospital, University of Queensland, Ipswich Road, Woolloongabba, QLD 4102, Australia. ${ }^{2}$ Department of Cardiothoracic Surgery, Princess Alexandra Hospital, University of Queensland, Ipswich Road, Woolloongabba, QLD 4102, Australia. ${ }^{3}$ Department of Diabetes and Endocrinology, Royal Brisbane Hospital, University of Queensland, Bowen Bridge Road, Herston QLD 4029, Australia. ${ }^{4}$ Department of Intensive Care, The Wesley Hospital, 451 Coronation Drive, Auchenflower, QLD 4066, Australia.

\section{Authors' contributions}

AK was involved in study design, data analysis and manuscript preparations. JO was involved in study design, sample collection and storage and data analysis. JM was involved in study design, and manuscript revision. MJ was involved in statistical analysis of data and manuscript revision. PK was involved in study design and manuscript preparation and revision. ED was involved in study design and manuscript preparation and revision. BV was involved in overall study design and supervision, data analysis, and manuscript preparation and revision. All authors read and approved the final manuscript.

\section{Competing interests}

The authors declare that they have no competing interests.

Received: 17 August 2010 Revised: 9 October 2010

Accepted: 26 November 2010 Published: 26 November 2010

\section{References}

1. Judd SE, Tangpricha V: Vitamin D deficiency and risk for cardiovascular disease. Am J Med Sci 2009, 338:40-44.

2. Hamilton B: Vitamin D and human skeletal muscle. Scand J Med Sci Sports 2010, 20:182-190.

3. Krishnan A, Ochola J, Venkatesh B: Vitamin D in critical illness. In Yearbook of Intensive Care and Emergency Medicine. Edited by: Vincent JL. Heidelberg: Springer-Verlag; 2010:273-81.

4. Zittermann A, Schleithoff SS, Götting C, Fuchs U, Kuhn J, Kleesiek K, Tenderich G, Koerfer R: Calcitriol deficiency and 1-year mortality in cardiac transplant recipients. Transplantation 2009, 87:118-124.

5. Munger KL, Zhang SM, O'Reilly E, Hernán MA, Olek MJ, Willett WC, Ascherio A: Vitamin D intake and incidence of multiple sclerosis. Neurology 2004, 62:60-65.

6. Hyppönen $\mathrm{E}$, Läärä $\mathrm{E}$, Reunanen $\mathrm{A}$, Järvelin MR, Virtanen SM: Intake of vitamin D and risk of type 1 diabetes: a birth-cohort study. Lancet 2001, 358:1500-1503.

7. Melamed ML, Michos ED, Post W, Astor B: 25-hydroxyvitamin D levels and the risk of mortality in the general population. Arch Intern Med 2008, 168:1629-1637.

8. Lee $P$, Nair $P$, Eisman JA, Center JR: Vitamin D deficiency in the intensive care unit: an invisible accomplice to morbidity and mortality? Intensive Care Med 2009, 35:2028-2032.

9. Van den Berghe G, Van Roosbroeck D, Vanhove P, Wouthers PJ, De Pourcq L, Bouillon R: Bone turnover in prolonged critical illness: effect of vitamin D. J Clin Endocrinol Metab 2003, 88:4623-4632.

10. Zella LA, Shevde NK, Hollis BW, Cooke NE, Pike JW: Vitamin D-binding protein influences total circulating levels of 1,25-dihydroxyvitamin D3 but does not directly modulate the bioactive levels of the hormone in vivo. Endocrinology 2008, 149:3656-3667.

11. Nierman DM, Mechanick Jl: Bone hyperresorption is prevalent in chronically critically ill patients. Chest 1998, 114:954-955.

12. Lee $P$, Eisman JA, Center JR: Vitamin $D$ deficiency in critically ill patients. N Engl J Med 2009, 360:1912-1914.

13. Vincent JL, Sakr Y, Sprung CL, Ranieri VM, Reinhart K, Gerlach H, Moreno R, Carlet J, Le Gall JR, Payen D: Sepsis occurrence in Acutely III Patients Investigators: sepsis in European intensive care units: results of the SOAP study. Crit Care Med 2006, 34:344-353.

14. Morgan TJ, Venkatesh B, Hall J: Crystalloid strong ion difference determines metabolic acid-base change during acute normovolaemic haemodilution. Intensive Care Med 2004, 30:1432-1437.

15. Jones G: Pharmacokinetics of vitamin D toxicity. Am J Clin Nutr 2008, 88:582S-586S.
16. Edwards $L$, Muller KE, Wolfinger RD, Qaqish BF, Schabengerger O: An R2 statistic for fixed effects in the linear mixed model. Stat Med 2008, 27:6137-6157.

17. Reddy GS, Tserng KY: Calcitroic acid, end product of renal metabolism of 1,25-dihydroxyvitamin D3 through C-24 oxidation pathway. Biochemistry 1989, 28:1763-1769.

18. Brenza HL, Kimmel-Jehan $C$, Jehan F, Shinki T, Wakino S, Anazawa $H$, Suda T, DeLuca HF: Parathyroid hormone activation of the 25hydroxyvitamin D3-1alpha-hydroxylase gene promoter. Proc Natl Acad Sci USA 1998, 95:1387-1391.

19. Zehnder D, Bland R, Williams MC, McNinch RW, Howie AJ, Stewart PM, Hewison M: Extrarenal expression of 25-hydroxyvitamin d(3)-1 alphahydroxylase. J Clin Endocrinol Metab 2001, 86:888-894.

20. Chun RF, Lauridsen AL, Suon L, Zella LA, Pike JW, Modlin RL, Martineau AR, Wilkinson RJ, Adams J, Hewison M: Vitamin D-binding protein directs monocyte responses to 25-hydroxy- and 1,25-dihydroxyvitamin D. J Clin Endocrinol Metab 2010, 95:3368-3376.

21. Lucidarme O, Messai E, Mazzoni T, Arcade M, du Cheyron D: Incidence and risk factors of vitamin $D$ deficiency in critically ill patients: results from a prospective observational study. Intensive Care Med 2010, 36:1609-1611.

22. Roth HJ, Schmidt-Gayk H, Weber H, Niederau C: Accuracy and clinical implications of seven 25-hydroxyvitamin D methods compared with liquid chromatography-tandem mass spectrometry as a reference. Ann Clin Biochem 2008, 45:153-159.

\section{doi:10.1186/cc9341}

Cite this article as: Krishnan et al: Acute fluid shifts influence the assessment of serum vitamin D status in critically ill patients. Critical Care 2010 14:R216.

\section{Submit your next manuscript to BioMed Central and take full advantage of:}

- Convenient online submission

- Thorough peer review

- No space constraints or color figure charges

- Immediate publication on acceptance

- Inclusion in PubMed, CAS, Scopus and Google Scholar

- Research which is freely available for redistribution 